\title{
Contrasting wind patterns and toxigenic phytoplankton in the southern Benguela upwelling system
}

\author{
A. Fawcett ${ }^{1}$, G. C. Pitcher ${ }^{2, *}$, S. Bernard ${ }^{1}$, A. D. Cembella ${ }^{3}$, R. M. Kudela ${ }^{4}$ \\ ${ }^{1}$ Department of Oceanography, University of Cape Town, Private Bag, Rondebosch 7700, Cape Town, South Africa \\ ${ }^{2}$ Marine and Coastal Management, Private Bag X2, Rogge Bay 8012, Cape Town, South Africa \\ ${ }^{3}$ Alfred Wegner Institute, Am Handelshafen 12, 27570 Bremerhaven, Germany \\ ${ }^{4}$ Ocean Science Department, University of California, Santa Cruz, 1156 High Street, Santa Cruz, California 95064, USA
}

\begin{abstract}
The southern Namaqua shelf of the Benguela upwelling system, downstream of the Cape Columbine upwelling cell, is frequently subjected to a variety of harmful algal bloom (HAB) phenomena. Here, winds dictate most physical processes that are important to the development of HABs. Toxic algal cell concentrations and distributions, in relation to their respective toxin content, are compared over 2 autumn periods in successive years which exhibited clearly different wind patterns and hydrographic responses. During the first study period (15 March to 6 April 2005), several periods of relaxation from upwelling-favourable winds were associated with poleward nearshore currents and increasing levels of stratification. The phytoplankton community was dominated by dinoflagellates, including Dinophysis spp. and Protoceratium reticulatum, responsible for the production of toxins associated with diarrhetic shellfish poisoning and yessotoxins, respectively. In contrast, the subsequent study period (7 to 23 March 2006) was characterised by persistent upwelling-favourable winds, equatorward near-surface currents, and a cooler, moderately mixed water column. The phytoplankton assemblage was co-dominated by Pseudo-nitzschia spp. and Chaetoceros spp.; domoic acid concentrations corresponded closely with cell concentrations of Pseudo-nitzschia spp. Contrasting wind patterns, and their influence on water column structure and mesoscale circulation, led to predictably different assemblages of phytoplankton life-forms and their associated toxins.
\end{abstract}

KEY WORDS: Southern Benguela $\cdot$ Upwelling $\cdot$ Harmful algal bloom $\cdot$ Diatom $\cdot$ Dinoflagellate $\cdot$ Algal toxins

Resale or republication not permitted without written consent of the publisher

\section{INTRODUCTION}

Harmful algal blooms (HABs) are a regular feature of the west coast of South Africa, particularly during the latter part of the upwelling season (Pitcher et al. 1998, Pitcher \& Calder 2000). Such blooms are usually attributed to dinoflagellates, with harmful effects typically associated with either the toxicity of some species or the collapse of high biomass leading to anoxia (Pitcher et al. 1998). In this region, where most hydrodynamic processes on the continental shelf are governed by the prevailing winds (Pitcher et al. 1998), phytoplankton assemblages are highly responsive to synoptic weather and wind patterns. Wind-driven processes therefore determine the presence and accumulation of HAB species through their impact on mixed layer dynamics, influencing life-form and species selection and development, and, as a result of mesoscale circulation patterns, affecting bloom retention and advection (Pitcher \& Nelson 2006).

Topographical variation in the coastline of the southern Benguela gives rise to discrete upwelling cells at Hondeklip Bay, Cape Columbine and the Cape Peninsula (Nelson \& Hutchings 1983). Wind-induced 
upwelling in the southern Benguela is highly seasonal due to shifts in the position of the South Atlantic High; the upwelling season extends from September to March, with upwelling reaching a maximum in the austral spring and summer (Nelson \& Hutchings 1983). The present study focuses on the greater St. Helena Bay region, where the shelf broadens downstream of the Cape Columbine upwelling cell at $33^{\circ} \mathrm{S}$ (Fig. 1). This area is characterised by high phytoplankton biomass, as identified by remotely sensed chlorophyll data (Pitcher \& Weeks 2006), and is particularly susceptible to the development of HABs during the latter half of the upwelling season, when the contribution of dinoflagellates to the phytoplankton community is greatest. The high productivity is a result of: (1) the periodic resupply of nutrients to the euphotic zone through upwelling; $(2)$ the relative stability of the physical environment; and (3) retentive circulation in the region (Pitcher et al. 1992).

A conceptual model of red tide formation in St. Helena Bay has been presented by Pitcher \& Nelson (2006). During upwelling, northward flow dominates and an equatorward coastal jet forms off Cape

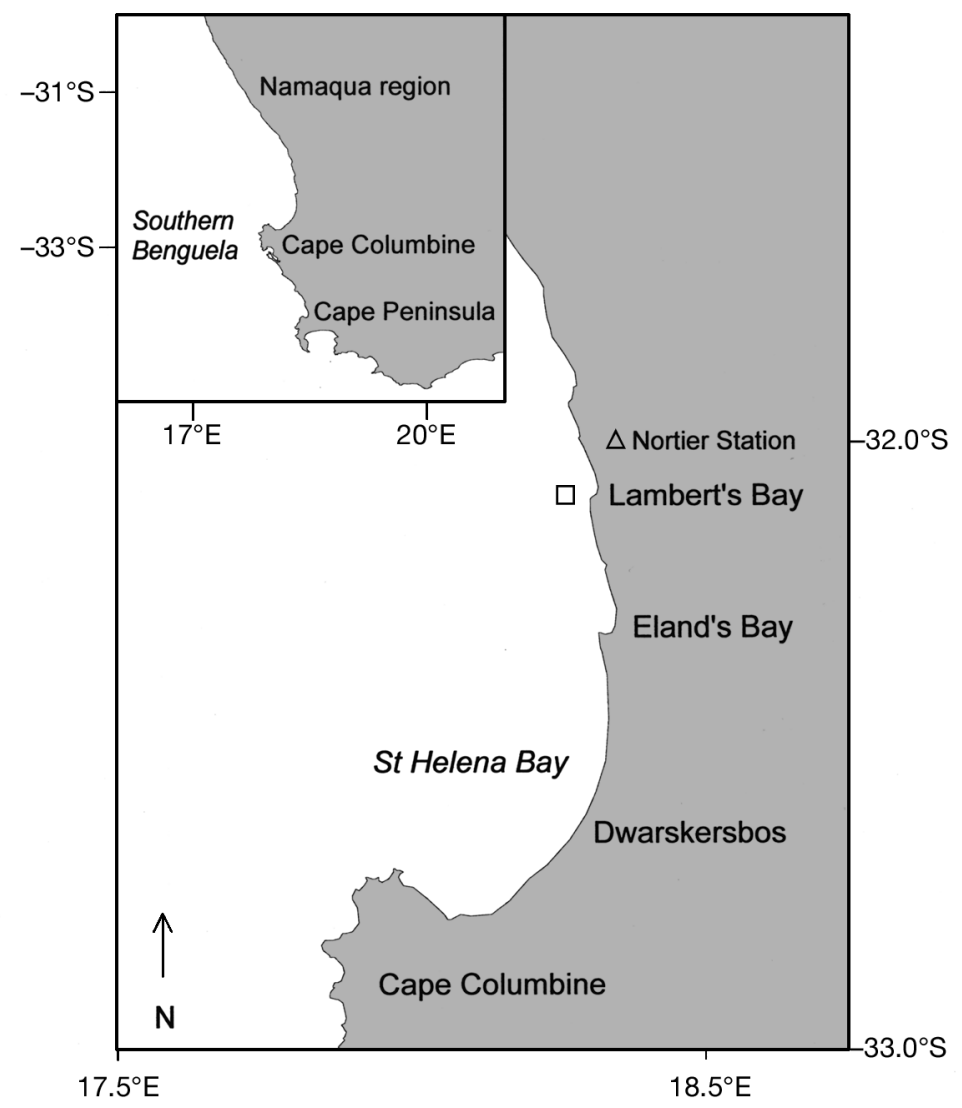

Fig. 1. Mooring and sampling location (ㅁ) $3.5 \mathrm{~km}$ offshore from Lambert's Bay on the southern Namaqua shelf, and the Nortier weather station location $(\Delta) 8.5 \mathrm{~km}$ inland
Columbine, where the shelf is narrow and steep (Nelson \& Hutchings 1983). Under these conditions, a plume of cold water extends northwards from Cape Columbine and the jet is separated from the coast to the north of the Cape, where the bottom relief is more gently sloping and the bathymetric influence less conspicuous. Although the surface drift is predominantly northerly, across-shelf, tidal, and inertial currents are more evident in this nearshore environment downstream of the upwelling centre. In addition to the upwelling off Cape Columbine, a narrow strip of upwelling may extend along the coast of St. Helena Bay to the north of Dwarskersbos (Taunton-Clark 1985). These observations are supported by the patterns of circulation within the model of Penven et al. (2000), whereby equatorward wind forcing produces a cyclonic eddy in the lee of Cape Columbine that contributes to the creation of a dynamic boundary between the coastal and offshore domains. The windinduced upwelling plume off Cape Columbine tends, therefore, to isolate the nearshore area from the offshore domain, thereby inducing retention on the coastal side of the plume. The limited across-shelf exchange of water is depicted in the clear and consistent delineation of phytoplankton assemblages representing the offshore and nearshore regions, with dinoflagellates, representative of the latter stages of succession, dominating the nearshore region (Pitcher \& Nelson 2006). Under upwelling conditions, dinoflagellates tend to accumulate in a region of convergence created by the narrow belt of inshore upwelling and the equatorward coastal jet. Wind relaxation or reversal is typically associated with the shoreward accumulation of dinoflagellate blooms, and the development of an inshore counter-current results in their general southward progression. The inshore poleward current is considered to be driven by a negative pressure gradient created by the separation of the equatorward jet from the coast by Cape Columbine (Gan \& Allen $2002 a, b)$, further contributing to retentive circulation within the region.

In the present study, the influence of changing wind patterns on the presence of different phytoplankton life-forms and associated algal toxins is illustrated. A mooring deployed in the nearshore environment downstream of Cape Columbine provided time series data for monitoring bloom development, and formed the focus of the data collection programme. Data are compared from 2 study periods during the latter part of the upwelling season in 2005 and 2006. Although these studies took place at similar times of the year, the contrasting interannual wind patterns, specifically their influence on water column structure and mesoscale circulation, were used to illustrate the responsive nature of phytoplankton assemblages. 


\section{MATERIALS AND METHODS}

Sampling was carried out at a single location, $3.5 \mathrm{~km}$ off Lambert's Bay, in $52 \mathrm{~m}$ of water (Fig. 1), during 2 study periods, one of $23 \mathrm{~d}$ (15 March to 6 April 2005) and the other $17 \mathrm{~d}$ (7 to 23 March 2006). Temperature and chlorophyll fluorescence (reported as $\mathrm{mg} \mathrm{m}^{-3} \mathrm{chl}$ a) profiles were obtained daily with a Sea-Bird CTD profiler (SBE19, Sea-Bird Electronics) and WETstar fluorometer (WET Labs). Chlorophyll values from the fluorometer deployed on the CTD compared favourably with extracted chlorophyll values obtained from coincident water samples during the 2 study periods. Phytoplankton samples were taken from NIO bottle samples at the surface and $5 \mathrm{~m}$ depth, fixed in buffered formalin at a final concentration of $0.5 \%$, and counted using the Utermöhl method (Hasle 1978). The instrument package on the mooring included a $30 \mathrm{~m}$ Apprise Technologies thermistor chain and a $300 \mathrm{kHz}$ RDI Workhorse acoustic Doppler current profiler (ADCP). Power management and the acquisition, storage, and transmission of data on the mooring were controlled by an Ocean-i Sensor Unit. During the 2005 study, data were collected from all instruments simultaneously for 2 min every half hour. These data were stored on-board and could be accessed remotely via cell phone telemetry. Data from the mooring were unavailable for the initial $4 \mathrm{~d}$ of the study. For the duration of the 2006 study, instruments were deployed on the mooring in selflogging mode and collected data every $10 \mathrm{~min}$. Wind data were obtained from R. M. Young wind sensors at the Lambert's Bay Nortier station of the South African Weather Service, located $8.4 \mathrm{~km}$ north-east of the sampling location (Fig. 1).

Water current data were rotated by $21.5^{\circ}$ to the east to be aligned to true (rather than magnetic) north. The coastline runs approximately north-south at the mooring location; rotated currents are therefore considered to be aligned approximately alongshore and acrossshelf. Wind data were plotted as the direction towards which the wind was blowing to ease visualisation of the wind data with the current data. Filtered data were generated using a pl64 filter (Limeburner 1985) that has a half-amplitude period of $33 \mathrm{~h}$ and a half-power period of $38 \mathrm{~h}$. The filter removes energy at periods shorter than $38 \mathrm{~h}$, thus removing tidal, diurnal and inertial signals, while preserving energy at lower frequencies including the mean (Limeburner 1985; as cited in Largier et al. 1993).

Water samples of $200 \mathrm{ml}$ were collected at the surface and $5 \mathrm{~m}$, filtered through Whatman GF/F filters and frozen in liquid nitrogen prior to analysis for toxins. Samples collected during 2005 were analysed for lipophilic toxins and domoic acid (DA) by HPLC coupled with tandem mass spectrometry (LC-MS/MS) according to modifications of the Stobo et al. (2005) method for rapid multiple toxin analysis of lipophilic shellfish toxins. Filters were extracted with $100 \% \mathrm{MeOH}$ in a Fast-Prep apparatus (BeadBeater, BioSpec Products) followed by centrifugation and filtration of extracts prior to injection into the LCMS/MS system. Samples were analysed in MRMmode for the presence of diarrhetic shellfish poisoning (DSP) toxins: okadaic acid (OA, OA-8) and dinophysistoxins (DTX1, DTX2), yessotoxins (YTX), gymnodimine (GYM), azaspiracid (AZA), pectenotoxin (PTX2, PTX2-sa, PTX11, PTX12), spirolides (SPX) and DA. Chromatographic separation was achieved on a silica C-8 column (Hypersil $50 \times 2.1$ $\mathrm{mm}$; particle size $3 \mu \mathrm{m}$ ) with a linear elution gradient of $5 \mathrm{mM}$ ammonium acetate $(\mathrm{pH} 6.8)$ in water:acetonitrile $(95 \%, \mathrm{vol} / \mathrm{vol})$. Mass spectral measurements were carried out on a triple quadrupole mass spectrometer (API 4000 QTrap, ABI-Sciex) with turbospray ionization in negative ion mode. Samples collected during 2006 were analysed for particulate DA, processed according to the method of Pocklington et al. (1990) using HPLC with fluorescence detection and by competitive ELISA (Kleivdal et al. 2007).

\section{RESULTS AND DISCUSSION}

\section{Winds}

Winds prior to the 2005 study were predominantly southerly and upwelling-favourable (Fig. 2a). Following the start of the study, the wind reversed to northwesterly from 15 to 20 March before reverting to southerly winds. Two further periods of relaxation of upwelling-favourable winds of $2 \mathrm{~d}$ duration were recorded from 26 to 27 March and 4 to 5 April. The 2006 study was preceded by offshore winds from 4 to 6 March (Fig. 2b). Winds remained predominantly southerly and upwelling-favourable for the duration of the study, with a single $2 \mathrm{~d}$ relaxation event (18 to 19 March). Wind patterns for the 2 periods of study were thus significantly different despite taking place at similar times of the year.

Prevailing winds in the southern Benguela are southerly during summer, determined by the location of the South Atlantic High pressure system, the pressure field over the African subcontinent, and eastward moving cyclones (Nelson \& Hutchings 1983). Southerly winds are deflected around Cape Columbine and blow with an onshore component to the north of Cape Columbine (Nelson \& Hutchings 1983), consistent with the prevailing south-westerly winds during the study periods. At the event scale, periods of relaxation and 


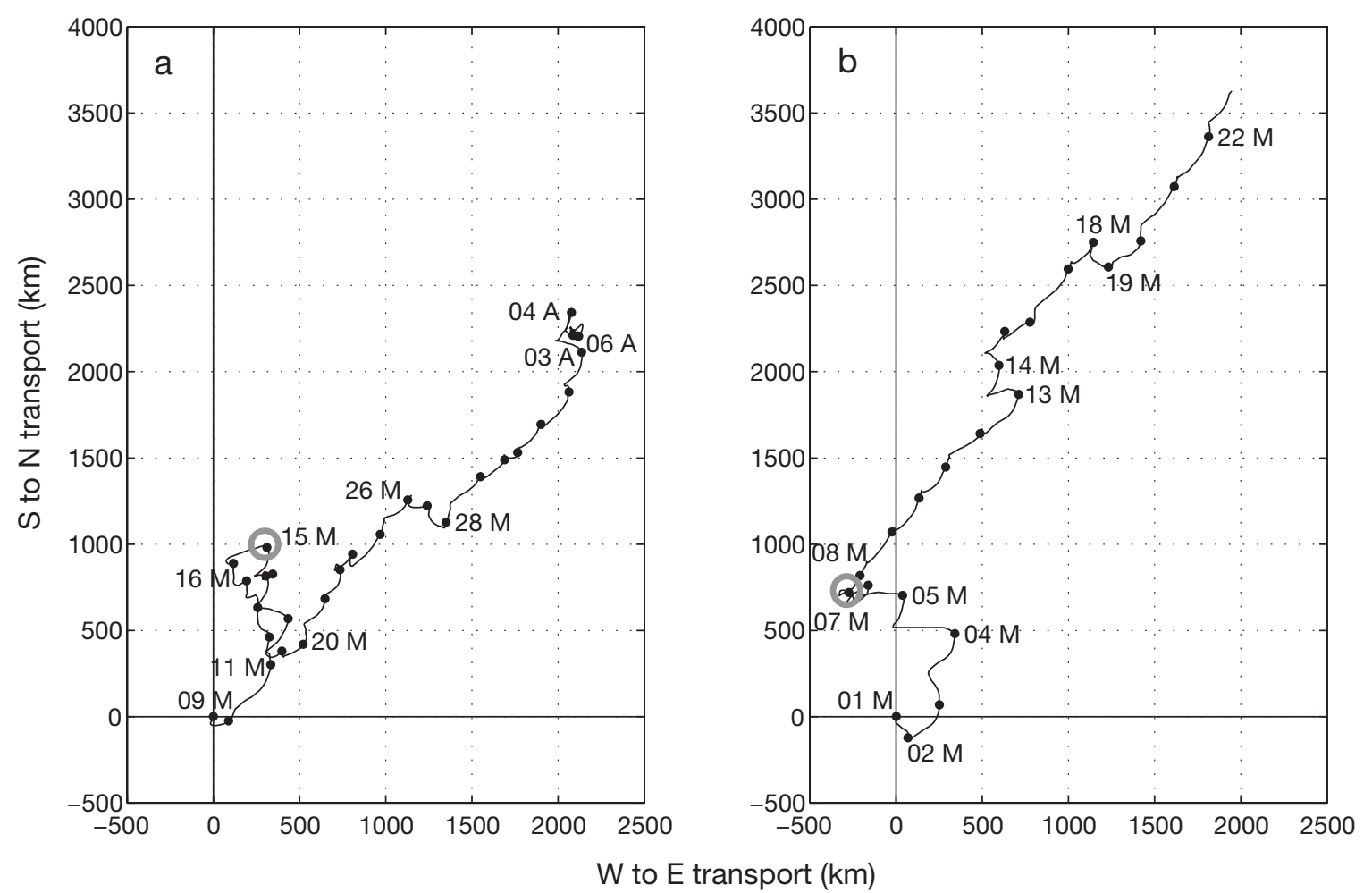

Fig. 2. Wind data from Lambert's Bay Nortier weather station for: (a) 9 March to 6 April 2005; and (b) 1 to 23 March 2006 . The plots commence $7 \mathrm{~d}$ prior to the study periods in both years. Markers and dates are positioned at midnight. Data start at the origin $(0,0)$. Grey circles indicate the start of the study periods. M: March; A: April

reversal of southerly winds during summer months are attributed to the eastward passage of low pressure cells and associated frontal systems south of the continent, which lead to periodic weakening of the South Atlantic High and modulation of the upwelling cycle with a period of 3 to 6 d (Nelson \& Hutchings 1983). Towards the end of summer and autumn, the pressure gradients responsible for upwelling-favourable winds weaken, leading to more prolonged periods of wind relaxation and reversal later in the upwelling season (Pitcher et al. 1992), such as those observed during the 2005 study. Other systems that may lead to occasional modulation of upwelling-favourable winds during summer are west coast troughs and coastal lows, which propagate as a type of Kelvin wave around the South African coast (Risien et al. 2004).

Whilst wind patterns in both the 2005 and 2006 studies were dominated by upwelling-favourable winds, there were several sustained periods of wind relaxation and reversal during the 2005 study, typical of late summer. Net equatorward wind transport in 2005 therefore totaled only $1350 \mathrm{~km}$ over the $23 \mathrm{~d}$ study period, while in 2006 upwelling-favourable winds reversed only briefly on a single occasion; consequently net equatorward transport totaled $2900 \mathrm{~km}$ over the $17 \mathrm{~d}$ studied.

\section{Response of surface currents to winds}

Near-surface currents were initially southward in 2005 in response to north-westerly winds (Fig. 3a). Flow reversed to northward on 21 March, following reversal to upwelling-favourable winds, with currents becoming southward again from 23 to 28 March and 3 to 5 April, consistent with the relaxation and reversal of equatorward winds. In 2006, near-surface currents were predominantly equatorward in response to persistent upwelling-favourable winds (Fig. 3b). Net flow in the nearshore region was therefore poleward in 2005, with a net transport of $16 \mathrm{~km}$ to the south, in contrast to net equatorward flow in 2006, with a net transport of $46 \mathrm{~km}$ to the north. Correspondingly, mean currents were southward throughout the water column during the study in 2005 (Fig. 4a), whilst in 2006 mean near-surface currents $(<11 \mathrm{~m}$ depth) were northward.

Alongshore wind and near-surface current data were well correlated, with the magnitude of the local wind reversal dictating the magnitude of the current response (Fig. 5). In both years, near-surface current reversals lagged wind reversals; the lag in 2005 was $8 \mathrm{~h}$ (Pearson correlation coefficient, $\mathrm{r}^{2}=0.52$, $\mathrm{n}=409, \mathrm{p}<0.05)$, while in 2006 the lag period was 


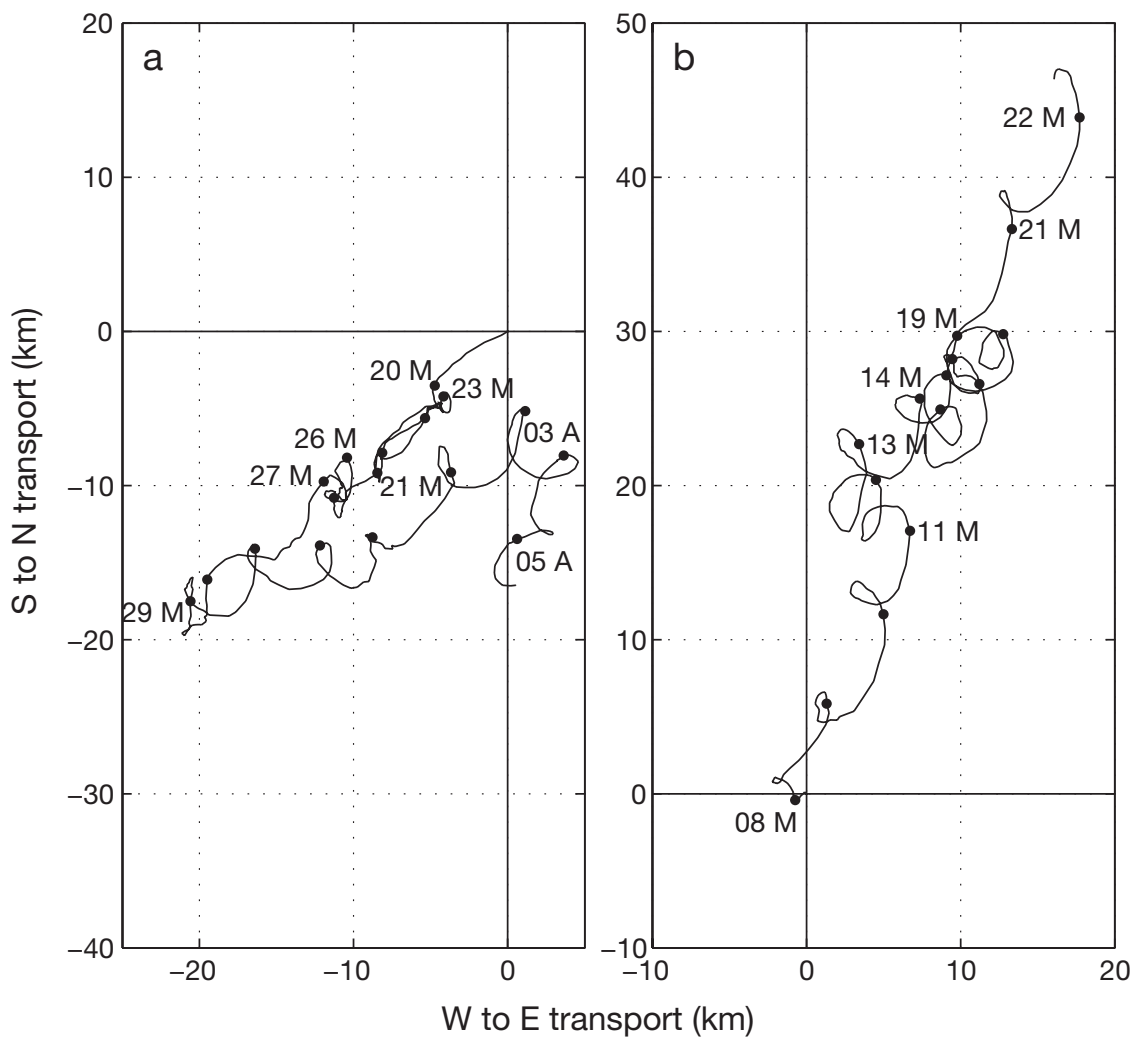

Fig. 3. Acoustic Doppler current profiler (ADCP) current vectors for the $5 \mathrm{~m}$ depth bin from the mooring for: (a) 19 March to 5 April 2005; and (b) 8 to 22 March 2006. Markers and dates are positioned at midnight. Data start at the origin $(0,0)$. ADCP data commence $4 \mathrm{~d}$ after the start of the study period in 2005 and $1 \mathrm{~d}$ after the start in 2006

$7 \mathrm{~h}\left(\mathrm{r}^{2}=0.6, \mathrm{n}=352, \mathrm{p}<0.05\right)$. The intercept of the regression line at the optimum lag period was negative in both years $\left(-3.6 \mathrm{~cm} \mathrm{~s}^{-1}\right.$ in $2005,-2 \mathrm{~cm} \mathrm{~s}^{-1}$ in 2006, Fig. 6) implying poleward flow in the absence of wind.

Our results are in keeping with previous observations of current flow and reversal in the St. Helena Bay region as predominantly barotropic and dominated at the event scale by wind-related alongshore variation associated with synoptic weather (Holden 1985). Lag times between local wind and current reversals, and the negative intercept of the regression line at the optimum lag period during the 2005 and 2006 study periods, are consistent with observations made off California during the Coastal Ocean Dynamics Experiment (CODE) (Winant et al. 1987). The results of these studies illustrate the responsive nature of currents to local wind forcing, and imply that nearshore poleward flow during periods of wind relaxation may be forced by alongshore pressure gradients that develop due to the interaction of alongshore upwelling currents with coastal capes (Gan \& Allen 2002a,b). Drift card trajectories from the St. Helena Bay region have shown northward current flow to dominate in summer with an inshore counter-current developing occasionally, becoming more persistent in autumn (Duncan \& Nell 1969). These flow patterns are consistent with our data; however, a higher frequency of southward flow was observed during wind relaxations in 2005, typical of autumn, while the persistent southerly winds and northward flow of 2006 are more representative of summer conditions.

High frequency radar data collected off the California coast confirm both the response of subtidal currents to local winds and the development of poleward flow in the nearshore region equatorward of headlands during periods of weakening and relaxation of upwelling-favourable winds (Kaplan et al. 2005, Kaplan \& Largier 2006). Consequently, across-shelf variability is observed with more persistent and stronger equatorward flow offshore, leading to across-shelf shear in alongshore flow (Kaplan et al. 2005, Kaplan \& Largier 2006). This is similar to previous observations of across-shelf flow patterns in the St. Helena Bay area (e.g. Pitcher \& Nelson 2006), which contribute to retentive circulation in the region. The response of near-surface currents to changes in wind forcing in the present study support the conceptual model of Pitcher \& Nelson (2006), and the similarity to data collected downstream of California headlands indicates that the Cape Columbine headland is critical in determining the response of currents in the St. Helena Bay region under conditions of wind relaxation.

\section{Water column structure}

Changes from upwelling-favourable winds and associated currents to periods of relaxation and nearshore poleward currents influence mixing depth and water column structure, which are important factors in regulating and altering competitive conditions for the phytoplankton community through changes in light and nutrient availability. A modulated upwelling cycle of 3 to $6 \mathrm{~d}$ is typical of the Cape Columbine cell (Nelson \& Hutchings 1983). During active upwelling, equatorward winds are associated with northward shelf currents and a drop in sea surface temperature (SST). Relaxation phases are 

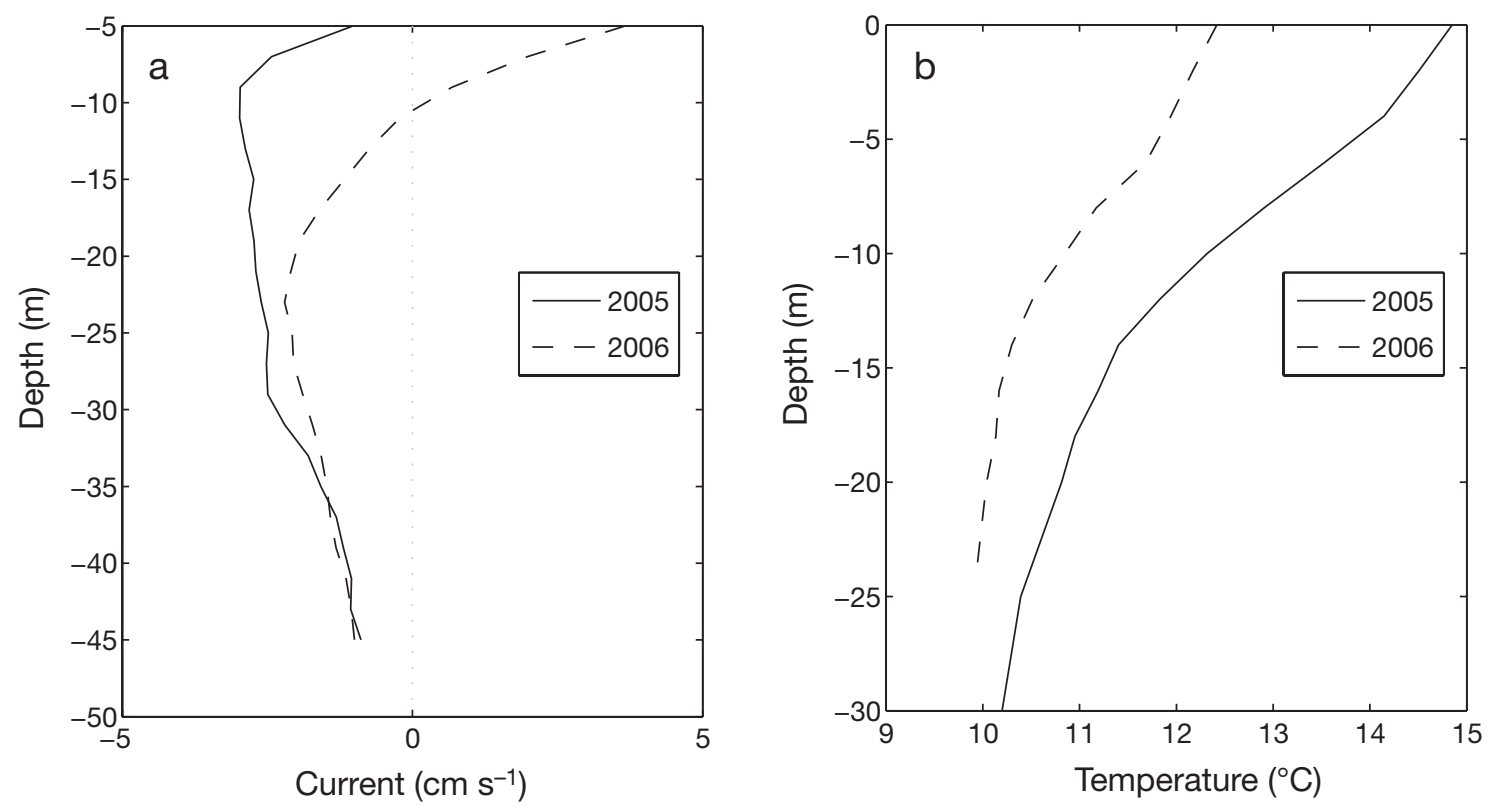

Fig. 4. (a) Mean alongshore current profiles from ADCP for the depth bins between 5 and $45 \mathrm{~m}$; and (b) mean temperature profiles from the mooring, for data between 19 March and 5 April 2005 and 7 and 22 March 2006. Positive current values are directed towards the north

characterised by reduced equatorward or poleward winds, southward flowing shelf currents and increasing SSTs (Jury \& Brundrit 1992).

During the 2005 study, SSTs were highly variable, ranging from 11 to $18.9^{\circ} \mathrm{C}$. Surface temperatures were well-correlated with near-surface currents (Fig. 7), confirming the association of warm water with south- ward currents and cool water with northward currents, consistent with the expected response to upwelling and relaxation events. A similar response of SSTs to near-surface currents was exhibited during the 2006 study; however, SSTs were lower and less variable, ranging from 9.8 to $15.0^{\circ} \mathrm{C}$, owing to the predominance of equatorward flow.
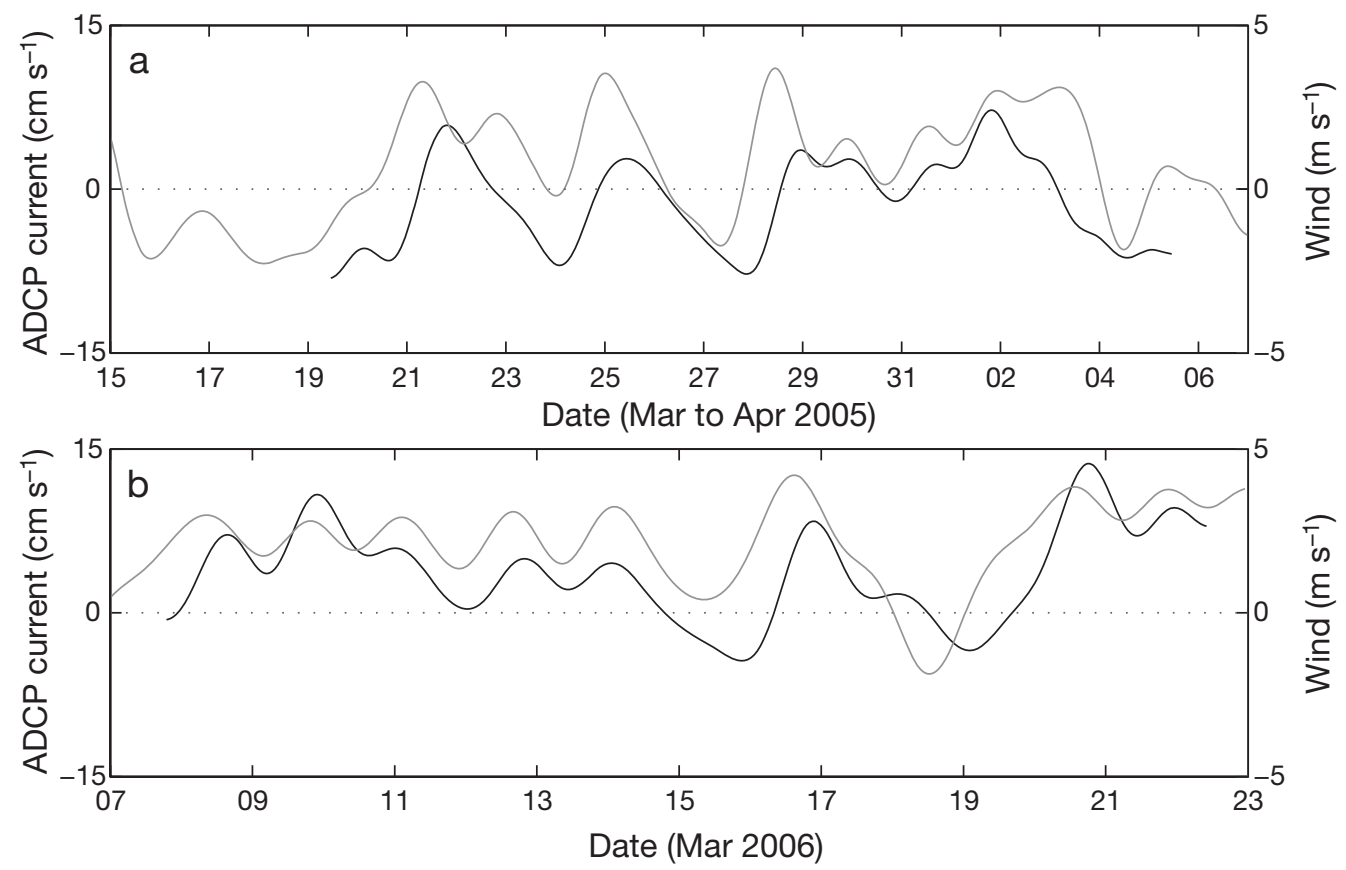

Fig. 5. Low-pass filtered alongshore current from ADCP for the $5 \mathrm{~m}$ depth bin (solid black line) and alongshore wind from Lambert's Bay Nortier weather station (solid grey line) for: (a) 15 March to 6 April 2005; and (b) 7 to 22 March 2006 


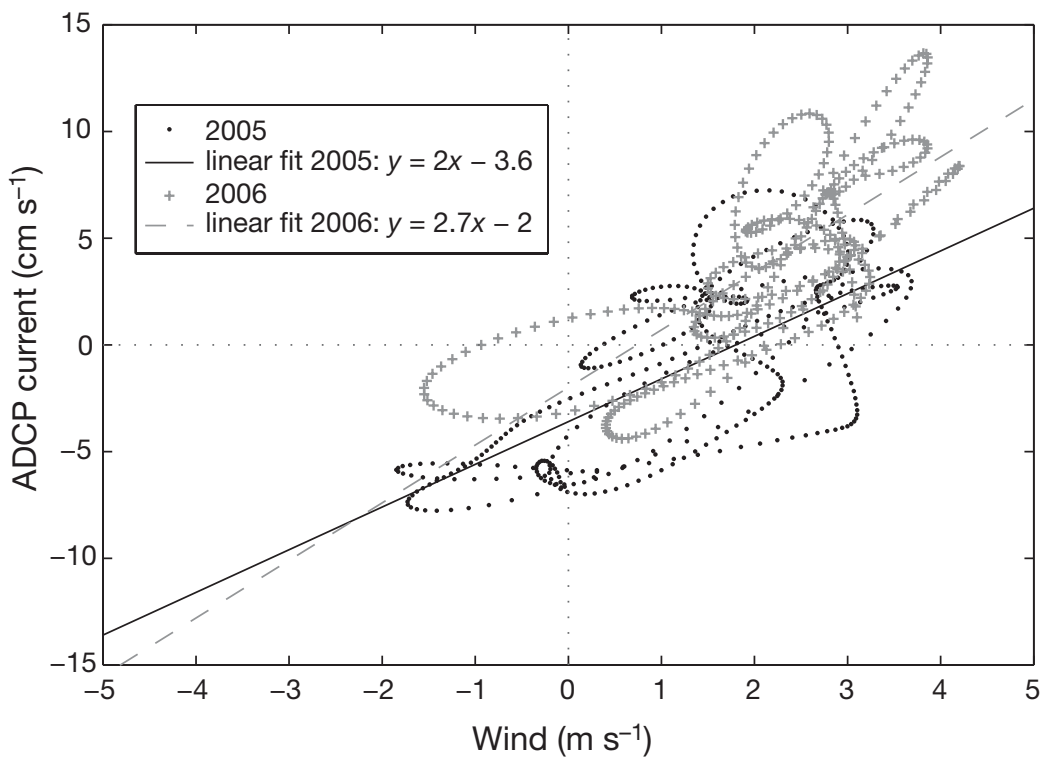

Fig. 6. Hourly values of low-pass filtered alongshore wind from Lambert's Bay Nortier weather station and alongshore current from ADCP for the $5 \mathrm{~m}$ depth bin at the optimum lag period for the study periods in 2005 (lag period $8 \mathrm{~h}$ ) and 2006 (lag period $7 \mathrm{~h}$ ). Linear regression lines for the 2 yr are shown

Increases in SST at the mooring location resulted from a combination of solar heating and advection. High levels of insolation in summer can lead to an average temperature increase of $0.65^{\circ} \mathrm{C} \mathrm{d}^{-1}$ over the upper $10 \mathrm{~m}$ mixed layer (Guastella 1992). Example heat budget calculations from 22 to 24 March 2005 indicate that the contribution of the available heat flux from insolation to the observed temperature changes on these days ranges from 20 to $40 \%$, and that advection is the dominant contributor to increasing temperatures (Fawcett 2006). Similar results were found during the CODE experiment on the northern Californian shelf, when 50 to $60 \%$ of the warming during relaxation of upwellingfavourable winds was attributed to solar heating, with most of the remaining warming accounted for by alongshore advection when currents reverse and flow poleward during wind relaxation (Send et al. 1987).

Conditions favouring inshore poleward flow within the greater St. Helena Bay region therefore not only promote retentive circulation, but also favour development of highly stratified conditions due to the responsiveness of currents to changes in local wind forcing, as illustrated by mean temperature profiles for the 2 periods of study (Fig. 4b). These profiles highlight the impact of differences in wind forced currents on water column structure; net poleward flow in 2005 was associated with warm stratified conditions, whereas persistent equatorward flow in 2006 was associated with a cooler, moderately mixed water column.

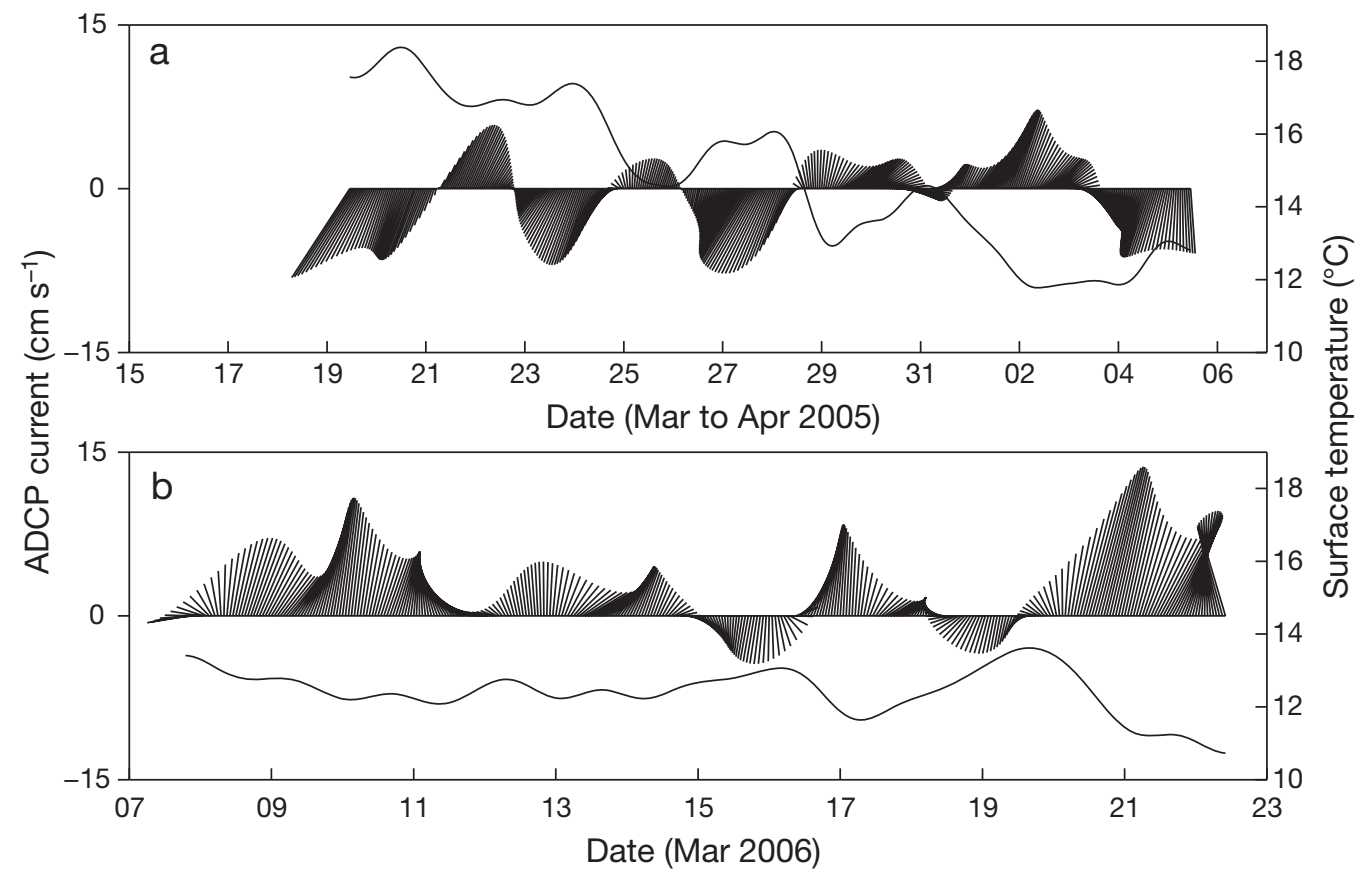

Fig. 7. Low-pass filtered ADCP current vectors for the $5 \mathrm{~m}$ depth bin and surface temperature from the mooring between: (a) 15 March and 6 April 2005; and (b) 7 and 22 March 2006 


\section{Phytoplankton response}

The relatively cool, well-mixed water column at the start of the 2005 study was associated with biomass levels of around $40 \mathrm{mg}$ chlorophyll a (chl a) $\mathrm{m}^{-3}$ (as determined by chlorophyll fluorescence) (Fig. 8a,b), and a diatom-dominated phytoplankton assemblage (Fig. 9a). A dramatic switch to a flagellate-dominated assemblage followed the intrusion of warm water from the north into the region of sampling on 16 March. Biomass declined and the concentration of coccolithophorids increased during this highly stratified period (17 to $23 \mathrm{March}$ ), associated with continuing poleward flow and maximum surface temperatures. During periods of intermediate stratification, associated with southward currents following brief periods of upwelling-favourable winds and northward currents, the phytoplankton population was dominated by dinoflagellates, predominantly Prorocentrum triestinum, with chl a concentrations reaching $170 \mathrm{mg} \mathrm{m}^{-3}$. During the 2006 study, the cooler, more mixed water column was associated with lower levels of biomass of 10 to

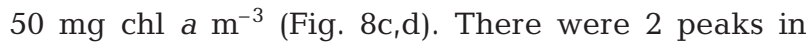
biomass around the thermocline on 15 and 19 March, where chl a concentrations reached $100 \mathrm{mg} \mathrm{m}^{-3}$, coincident with warming of surface waters to $13^{\circ} \mathrm{C}$. Consistently high diatom concentrations along with a low abundance of flagellates were associated with this cooler, more mixed water column (Fig. 9b).

The succession of differing life-forms of phytoplankton is driven by their adaptation to varying conditions of turbulence, thereby driving light and nutrient availability. Diatoms typically dominate in turbulent, nutrient-rich waters, whereas dinoflagellates tend to dominate in stratified, nutrient-poor environments (Margalef 1978), and coccolithophorids in warmer, oligotrophic waters (Smayda 1980). Although dinoflagellates have been observed to tolerate and occur under a large range of conditions, including those of pronounced vertical mixing and shear-stress, they tend to avoid the energylimited and major upwelling conditions favoured by diatoms (Smayda \& Reynolds 2001). Thus, levels of mixing and stratification are considered important physical processes in affecting life-form selection and distribution, grouping together phytoplankton with an affinity for, or the ability to withstand, similar environmental conditions (Pitcher \& Nelson 2006).

These processes are observed within the 2 periods of study; differing phytoplankton assemblages (incorporating the taxonomic groupings coccolithophorids, dinoflagellates and diatoms) dominate, coincident with variations in surface temperature and thus water column structure. Diatom-dominated assemblages are associated with cooler, relatively well-mixed water masses in both years; however, in 2005, changes in the phytoplankton community to dinoflagellate- and coccolithophorid-dominated assemblages were driven by wind-forced changes in water mass, leading to increasingly stratified conditions. Changes in biomass and phytoplankton community composition were often rapid, and were therefore attributed to advection and sequential changes rather than in situ growth and succession. Previous observations in the St. Helena Bay region have shown similar associations of phytoplankton life-forms with levels of mixing and stratification at varying temporal and spatial scales. Observations include the seasonal increase in dinoflagellates towards autumn as stratification increases (Pitcher \& Weeks 2006), the across-shelf delineation of phytoplankton with diatoms dominating offshore as mixed layer depth increases (Pitcher \& Nelson 2006), and the dominance of diatoms downstream of upwelling centres in cool, well-mixed waters following upwelling (Shannon \& Pillar 1986). Chl a satellite images from the 2 study periods, derived from Medium Resolution Imaging Spectrometer (MERIS) data using an experimental algorithm (Bernard et al. 2005), illustrate the differing spatial nature of the bloom events in response to the physical forcing. The 2005 study was characterised by the inshore appearance of a narrow band of high phytoplankton biomass, dominated by dinoflagellates, associated with nearshore poleward flow during wind relaxation and stratified conditions (Fig. 10a), again consistent with the observations and conceptual model of Pitcher \& Nelson (2006). In the 2006 study, persistent upwelling-favourable winds led to equatorward near-surface currents and a cooler, more mixed water column; Pseudo-nitzschia spp. co-dominated a spatially extensive diatom bloom (Fig. 10b). Thus, changes in phytoplankton life-form during the 2 periods of study can clearly be traced to the contrasting wind patterns and the responsive nature of currents and water column structure to these.

\section{Toxic species}

In 2005, the toxic species Dinophysis acuminata, D. fortii and Protoceratium reticulatum formed a small but important component of the high biomass dinoflagellate bloom dominated by Prorocentrum triestinum. Many Dinophysis spp. are known to contain DSP toxins, including OA and DTX (Yasumoto 1990). The occurrence of Dinophysis spp. is common on the west coast of South Africa (Pitcher \& Calder 2000) and the associated presence of DSP toxins in shellfish was first identified and attributed to D. acuminata in 1991 (Pitcher et al. 1993). Yessotoxins were first shown in 1997 to be produced by P. reticulatum in the coastal waters of New Zealand (Yasumoto \& Takizawa 1997), but these toxins 

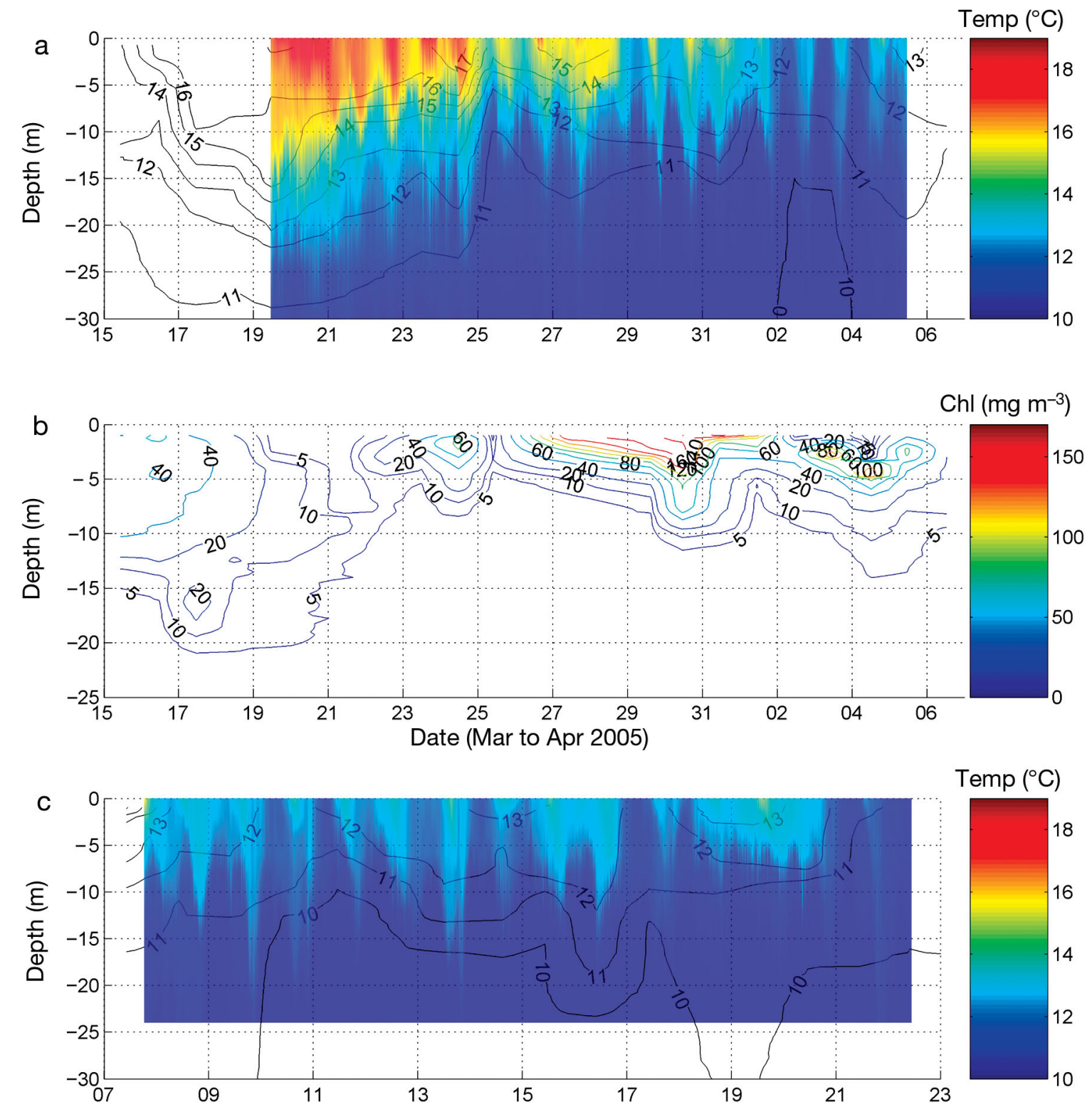

Temp $\left({ }^{\circ} \mathrm{C}\right)$
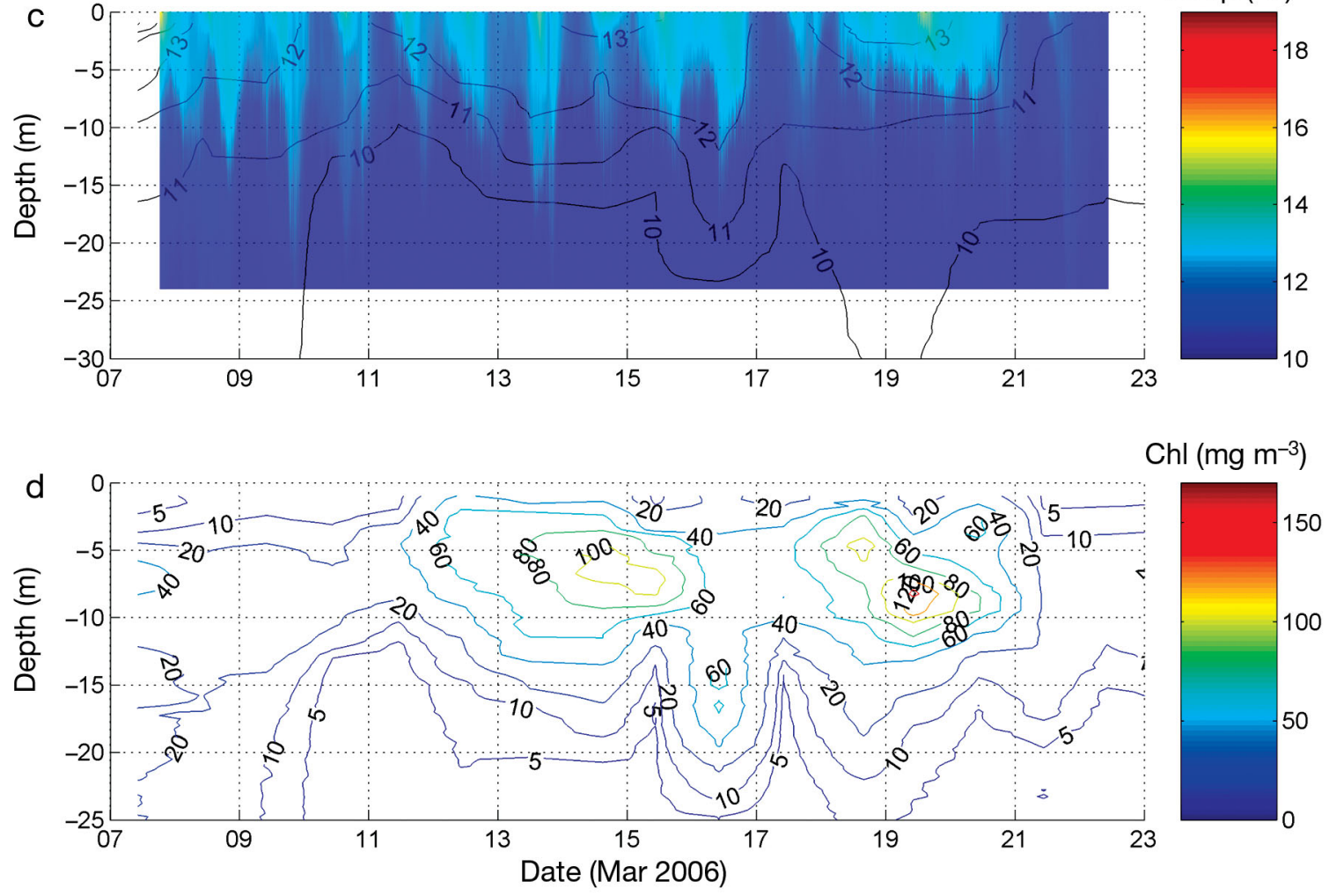

Fig. 8. (a,c) Temperature from mooring thermistor chain (colour plot) with daily CTD casts at mooring location (contour plot); and (b,d) daily chlorophyll profiles from fluorometer, for (a,b) 15 March to 6 April 2005; and (c,d) 7 to 22 March 2006 

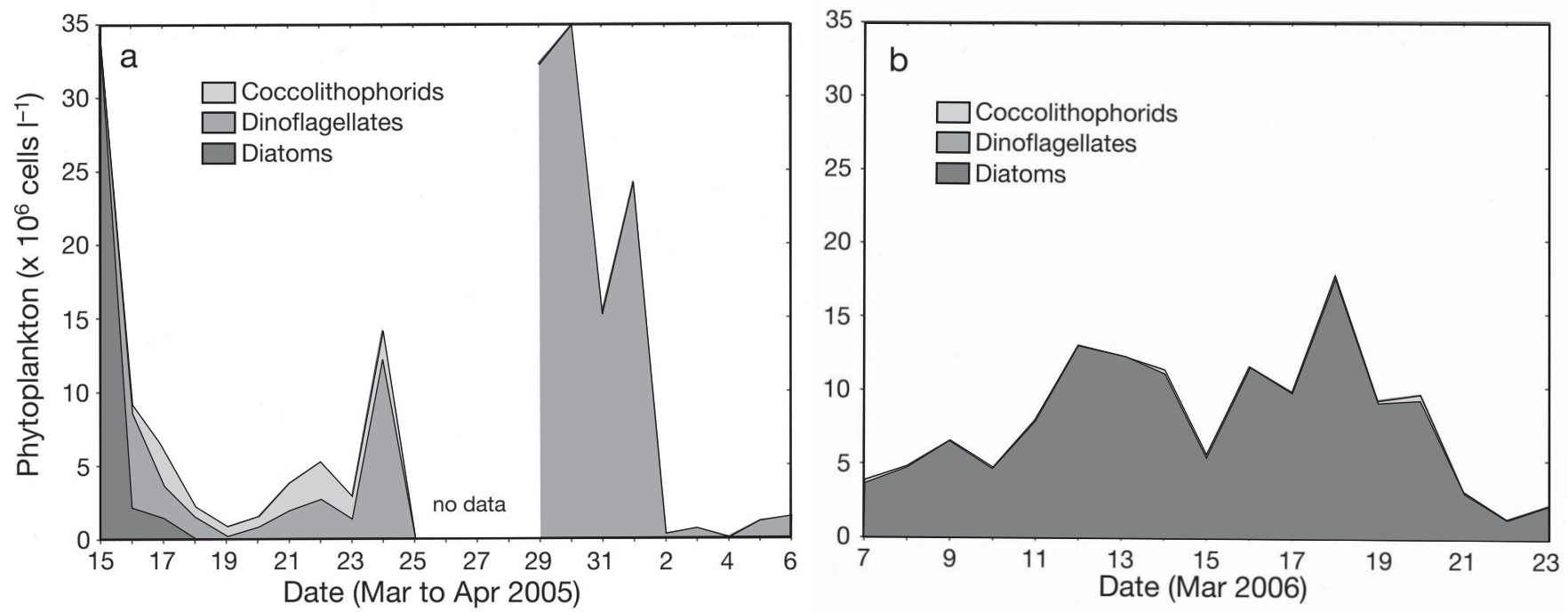

Fig. 9. Daily surface phytoplankton counts at mooring location for: (a) 15 March to 6 April 2005; and (b) 7 to 23 March 2006

are now found widely distributed in coastal and shelf waters. While YTX were originally classed among DSP toxins, they are now regarded as a distinct group as they do not induce diarrheagenic symptoms.

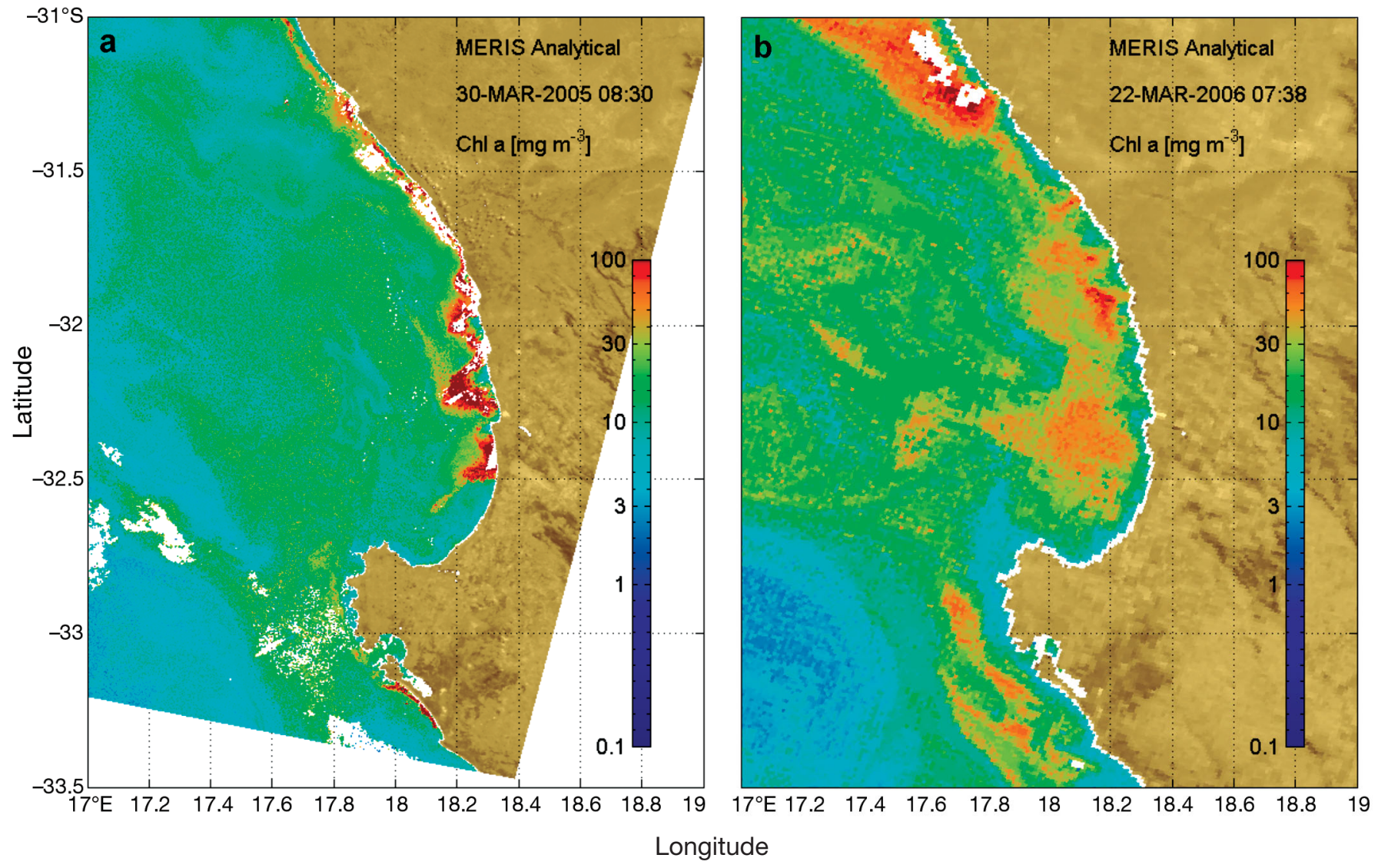

OA and YTX concentrations as extracted from filtered plankton field samples during the 2005 study corresponded closely with cell concentrations of Dinophysis spp. and Protoceratium reticulatum, respec-

Fig. 10. Medium Resolution Imaging Spectrometer (MERIS) chl a images of St. Helena Bay region for: (a) 30 March, 2005 and (b) 22 March 2006. Chlorophyll a levels were calculated using an experimental algorithm 
tively (Fig. 11a,b). This indicates that the toxin quota (e.g. OA or YTX concentration per cell) did not vary substantially over the bloom period under study. Interestingly, field samples also contained low amounts of PTX2, which is consistent with the occurrence of $D$. acuminata and $D$. fortii. However, OA was the only true DSP toxin found in these samples; DTX were not detected. The absence of DTX1 in the Benguela populations containing $D$. fortii is consistent with the biogeographical diversity found for this species. For example, DTX1 is produced in northern populations of $D$. fortii, but not in southern populations from Japan (Yasumoto \& Murata 1990). The recent report (Krock et al. in press) of YTX associated with blooms of $P$. reticulatum from the Benguela is the first confirmation of the presence of these toxins in the coastal waters of South Africa. In addition to the dominant parent compound YTX, small amounts $(<3 \%$ total molar) of arabinofuranosyl-YTX were present in field samples from the Benguela system. Nevertheless, the YTX profiles of field populations from the St. Helena Bay region are distinct from those of blooms of $P$. reticulatum from the North Sea.

During the 2006 study, Pseudo-nitzschia spp. co-dominated the diatom bloom along with Chaetoceros spp. Following the first record of amnesic shellfish poisoning (ASP) from mussels harvested from Prince Edward Island off the Canadian east coast in 1987 (Subba Rao et al. 1988), several Pseudo-nitzschia spp. have been reported to produce DA, the toxic agent responsible for ASP (Bates et al. 1998). Whilst several Pseudo-nitzschia spp. responsible for ASP are found in the Benguela, ASP has not previously been recorded in this region (Pitcher \& Calder 2000). In any case, total DA concentrations derived from filtered plankton samples collected during the 2006 study (Fig. 11c) closely tracked the total cell concentrations of Pseudonitzschia spp. This provides the first conclusive evidence for the presence of ASP toxins associated with Pseudo-nitzschia spp. in the Benguela system. Particulate DA concentrations during the study ranged from 0.1 to $3 \mu \mathrm{g} \mathrm{l}^{-1}$. Similar values have been detected during studies near California coastal upwelling zones, where DA lev-
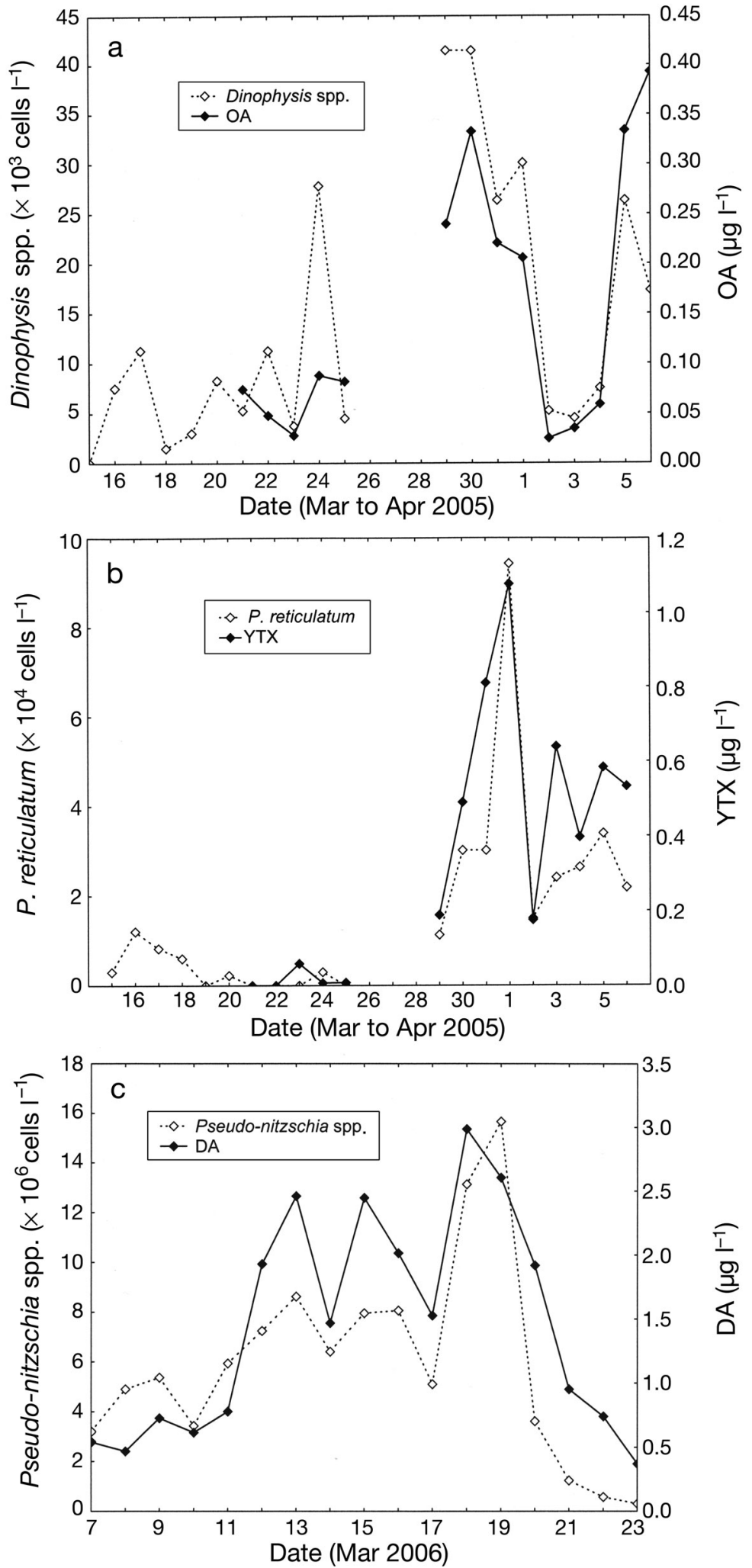

Fig. 11. Mean of surface and $5 \mathrm{~m}$ depth: (a) Dinophysis spp. cell counts and okadaic acid (OA) concentrations for 15 March to 6 April 2005; (b) Prorocentrum reticulatum cell counts and yessotoxin (YTX) concentrations for 15 March to 6 April 2005; and (c) Pseudo-nitzchia spp. cell counts and domoic acid (DA) concentrations for 7 to 23 March 2006 
els associated with Pseudo-nitzchia spp. ranged from 0.1 to $7.3 \mu \mathrm{g} \mathrm{l}^{-1}$ at varying sites, and were connected to sea lion mortalities in the region due to consumption of contaminated anchovies (Trainer et al. 2000).

\section{CONCLUSIONS}

The succession and selection of various functional groups of phytoplankton along mixing and nutrient gradients has been previously described; diatoms tend to dominate in well-mixed, nutrient-rich environments, dinoflagellates in more stratified, nutrient-poor environments and coccolithophorids in warmer, oligotrophic waters (e.g. Margalef 1978, Smayda 1980). In the present study, the physical forcing mechanisms driving the selection of differing life-forms of phytoplankton in the southern Benguela have been illustrated. Changes in wind forcing between 2005 and 2006, and the associated variations in surface currents and water column structure, resulted in dramatically different phytoplankton responses. Conditions in 2005 resulted in a numerically minor but nevertheless toxigenic subcomponent of the dinoflagellate assemblage producing both YTX and OA, while those in 2006 resulted in an extensive (spatially and temporally) DA event due to a bloom of Pseudo-nitzschia spp. These data are consistent with the conceptual model of Pitcher \& Nelson (2006), with variations in the distribution of phytoplankton life-forms associated with variability in mixed layer characteristics, and the appearance of dinoflagellate dominated populations in the nearshore region associated with nearshore poleward flow and warming of inshore waters during periods of relaxation from upwelling-favourable winds. The observations of differing phytoplankton life-forms and their associated algal toxins as a consequence of changes in wind forcing at similar times during the 2 years may be attributed to either interannual differences in wind forcing, or event-scale patterns persistent during the sampling periods. Episodic wind forcing in upwelling environments is known to create and alter sub-habitats favouring differing life-forms and species of phytoplankton, and thus lead to interruption and resetting of patterns of succession (Smayda 2000, Kudela et al. 2005). In the context of these studies it is not possible to resolve whether the observed differences are a function of sampling during particular periods in the upwelling cycle, or due to interannual variation in meteorological conditions and wind forcing, which led to more persistent changes in hydrodynamic conditions.

Although habitat preferences of dinoflagellate bloom species along onshore-offshore mixing-nutrient gradients have been suggested (Smayda \& Reynolds 2001), dinoflagellates representing life-forms I to VII (whose adaptations range from high nutrient, high irradiance, low mixing environments to those tolerant of lownutrient, higher energy shelf and upwelling environments) have been observed in the southern Benguela (Pitcher \& Nelson 2006). This indicates either the existence of a wide range of temporally and spatially varying sub-habitats in this region in response to physical forcing, or the tolerance of wide-ranging conditions by these dinoflagellate species. Even within sub-habitats that favour particular life-forms or species of phytoplankton, sub-habitat selection by a particular species is in part stochastic, requiring the species to be in the right place at the right time (Smayda \& Reynolds 2001). For these reasons, prediction of the presence of species or groups of species in the region based on hydrodynamic conditions remains challenging, beyond the switch from diatom to dinoflagellate or coccolithophorid dominated assemblages (Pitcher \& Nelson 2006). Thus, although the different phytoplankton assemblages dominating the 2 study periods were clearly related to the contrasting wind-driven hydrodynamics, these data also illustrate the potential difficulty of predicting specific HAB events and the presence of toxic genera.

Acknowledgements. We thank D. Calder and A. du Randt for their contribution to sample and data collection and analysis. The Benguela Current Large Marine Ecosystem Programme, Marine and Coastal Management, and the Department of Science and Technology's Frontier Programme provided funding and support for the Namaqua mooring and data collection. Analysis of toxins by LC-MS/MS was performed by B. Krock, Alfred Wegener Institute for Polar and Marine Research, with technical assistance by A. Müller. Funding for DA toxin analysis was provided by NOAA MERHAB grant \#NA04NOS4780239-02 (to R.M.K.).

\section{LITERATURE CITED}

Bates SS, Garrison DL, Horner RA (1998) Bloom dynamics and physiology of domoic-acid producing Pseudonitzschia species. In: Anderson DM, Cembella AD, Hallegraeff GM (eds) Physiological ecology of harmful algal blooms. NATO ASI Ser 41, Springer, Berlin, p 267-292

Bernard S, Balt C, Pitcher G, Probyn T, Fawcett A, du Randt A (2005) The use of MERIS for harmful algal bloom monitoring in the southern Benguela. In: Lacoste H (ed) Proceedings of the MERIS (A)ATSR Workshop 2005 (ESA SP-597), September 2005. ESRIN, Frascati, p 26-30 (published on CD-ROM)

Duncan CP, Nell JH (1969) Surface currents off the Cape Coast. Invest Rep Div Sea Fish S Afr 76:1-19

Fawcett A (2006) Multi-sensor mooring development and its use to characterize physical processes relevant to harmful algal bloom dynamics in the St. Helena Bay area, South Africa. MSc thesis, University of Cape Town

Gan J, Allen JS (2002a) A modeling study of shelf circulation off northern California in the region of the Coastal Ocean Dynamics Experiment. Part 1. Response to relaxation of upwelling winds. J Geophys Res C 107:C93123, doi:10.1029/2000JC000768 
Gan J, Allen JS (2002b) A modeling study of shelf circulation off northern California in the region of the Coastal Ocean Dynamics Experiment. Part 2. Simulations and comparisons with observations. J Geophys Res C 107:C113184, doi:10.1029/2001JC001190

Guastella LAM (1992) Sea surface heat exchange at St. Helena Bay and implications for the southern Benguela upwelling system. S Afr J Mar Sci 12:61-70

Hasle GR (1978) The inverted-microscope method. In: Sournia A (ed) Phytoplankton manual. UNESCO, Paris, p 88-96

Holden CJ (1985) Currents in St. Helena Bay inferred from radio-tracked drifters. In: Shannon LV (ed) South African ocean colour and upwelling experiment. Sea Fisheries Research Institute, Cape Town, p 97-109

Jury M, Brundrit GB (1992) Temporal organization of upwelling in the Southern Benguela ecosystem by resonant coastal trapped waves in the ocean and atmosphere. S Afr J Mar Sci 12:219-224

Kaplan DM, Largier JL (2006) HF radar-derived origin and destination of surface waters flowing past Bodega Bay, California. Deep-Sea Res II 53:2906-2930

Kaplan DM, Largier JL, Botsford LW (2005) HF radar observations of surface circulation off Bodega Bay (northern California, USA). J Geophys Res C 110:C10020, doi:10.1029/ 2005JC002959

Kleivdal H, Kristiansen SI, Nilsen MV and Briggs L (2007) Single-laboratory validation of Biosense Direct Competitative Enzyme-linked Immunosorbent Assay (ELISA) for the determination of domoic acid toxins in shellfish. J Assoc Off Anal Chem 90 (4):1000-1010

Krock B, Alpermann T, Tillman U, Pitcher GC, Cembella AD (in press) Yessotoxin profiles from cultures and planktonic field samples of the marine dinoflagellates Protoceratium reticulatum and Gonyaulux spinifera. Proc XII Int Conf Harmful Algae, Copenhagen, 4-8 Dec 2006

Kudela R, Pitcher G, Probyn T, Figueiras F, Moita T, Trainer V (2005) Harmful algal blooms in coastal upwelling systems. Oceanography 18(2):184-197

Largier JL, Magnell BA, Winant CD (1993) Subtidal circulation over the northern California shelf. J Geophys Res C 98(C10):18147-18180

Limeburner R (ed) (1985) CODE-2: moored array and largescale data report. WHOI Tech Rep 85-35. Woods Hole Oceanographic Institution, Woods Hole, MA, p 234

Margalef R (1978) Life-forms of phytoplankton as survival alternatives in an unstable environment. Oceanol Acta 1: 493-509

Nelson G, Hutchings L (1983) The Benguela upwelling area. Prog Oceanogr 12:333-356

Penven P, Roy C, Colin de Verdière A, Largier J (2000) Simulation of a coastal jet retention process using a barotropic model. Oceanol Acta 23:615-634

Pitcher GC, Calder D (2000) Harmful algal blooms of the southern Benguela current: a review and appraisal of monitoring from 1989 to 1997. S Afr J Mar Sci 22:255-271

Pitcher GC, Nelson G (2006) Characteristics of the surface boundary layer important to the development of red tide on the southern Namaqua shelf of the Benguela upwelling system. Limnol Oceanogr 51:2660-2674

Pitcher GC, Weeks SJ (2006) The variability and potential for prediction of harmful algal blooms in the southern Benguela ecosystem. In: Shannon V, Hempel G, Malanotte-Rizzoli P, Moloney C, Woods J (eds) Benguela: predicting a large marine ecosystem. Elsevier, Amsterdam, p 125-146
Pitcher GC, Brown PC, Mitchell-Innes BA (1992) Spatiotemporal variability of phytoplankton in the southern Benguela upwelling system. S Afr J Mar Sci 12:439-456

Pitcher GC, Horstman DA, Calder D (1993) The first record of diarrhetic shellfish poisoning on the South African coast. S Afr J Sci 89:512-514

Pitcher GC, Boyd AJ, Horstman DA, Mitchell-Innes BA (1998) Subsurface dinoflagellate populations, frontal blooms and the formation of red tide in the southern Benguela upwelling system. Mar Ecol Prog Ser 172:253-264

Pocklington R, Milley JE, Bates SS, Bird CJ, de Freitas ASW, Quilliam MA (1990) Trace determination of domoic acid in seawater and phytoplankton by high-performance liquid chromatography of the fluorenylmethoxycarbonyl (FMOC) derivative. Int J Environ Anal Chem 38:351-368

Risien CM, Reason CJC, Shillington FA (2004) Variability in satellite winds over the Benguela upwelling systems during 1999-2000. J Geophys Res C 109:C03010, doi:10.1029/ 2003JC001880

Send U, Beardsley RC, Winant CD (1987) Relaxation from upwelling in the Coastal Ocean Dynamics Experiment. J Geophys Res 92(C2):1683-1698

Shannon LV, Pillar SC (1986) The Benguela ecosystem. 3. Plankton. Oceanogr Mar Biol Annu Rev 24:65-170

Smayda TJ (1980) Phytoplankton species succession. In: Morris I (ed) The physiological ecology of phytoplankton. Studies in ecology, Vol 7. Blackwell, Oxford, p 493-570

Smayda TJ (2000) Ecological features of harmful algal blooms in coastal upwelling systems. S Afr J Mar Sci 22:219-253

Smayda TJ, Reynolds CS (2001) Community assembly in marine phytoplankton: application of recent models to harmful dinoflagellate blooms. J Plankton Res 23(5): $447-461$

Stobo LA, Lacaze JPCL, Scott AC, Gallacher S, Smith EA, Quilliam MA (2005) Liquid chromatography with mass spectrometry-detection of lipophilic shellfish toxins. J Assoc Off Anal Chem Int 88:1371-1382

Subba Rao DVS, Quilliam MA, Pocklington R (1988) Domoic acid-a neurotoxin amino acid produced by the marine diatom Nitzschia pungens in culture. Can J Fish Aquat Sci 45:2076-2079

Taunton-Clark J (1985) The formation, growth and decay of upwelling tongues in response to the mesoscale wind field during summer. In: Shannon LV (ed) South African Ocean Colour Experiment. Sea Fisheries Research Institute, Cape Town, p 47-61

Trainer VL, Adams NG, Bill BD, Stehr CM, Wekell JC, Moeller P, Busman M, Woodruff D (2000) Domoic acid production near California coastal upwelling zones, June 1998. Limnol Oceanogr 45(8):1818-1833

Winant CD, Beardsley RC, Davis RE (1987) Moored wind, temperature and current observations made during the Coastal Ocean Dynamics Experiments 1 and 2 over the northern California continental shelf and upper slope. J Geophys Res 92(C2):1569-1604

Yasumoto T (1990) Marine microorganisms toxins: an overview. In: Granéli E, Sundstrom B, Edler L, Anderson DM (eds) Toxic marine phytoplankton. Elsevier, New York, p 3-8

Yasumoto T, Murata M (1990) Polyether toxins involved in seafood poisoning. In: Hall S, Strichartz G (eds) Marine toxins: origin, structure, and molecular pharmacology. ACS Symposium Series, Washington, DC, p 20-132

Yasumoto T, Takizawa A (1997) Fluorometric measurement of yessotoxins in shellfish by high-pressure liquid chromatography. Biosci Biotechnol Biochem 61:1175-1177 